\title{
Retirement time planning of Indian expatriate in Umm Al Quwain region, a quasi experimental study from UAE
}

Thundiparampil SJ*

*Corresponding author:

Mrs. Smitha J. Thundiparampil, ADON, Department of nursing, UAQ Medical District, UAE

Email: thundiparambil2@gmail.com

\section{Information about the article:}

Received: Jan. 17, 2019

Accepted: Feb. 20, 2019

Published online: Dec. 27, 2019

Publisher

Nepal Health Research Society, Bahundhara -6, Gokarnesowor Municipality, Kathmandu, Nepal

eISSN 2382-5545, ISSN 2676-1343 (Print)

(C) The Author(s). 2019

Content licensing: CC BY 4.0

\begin{abstract}
Background

United Nations (2015) projected that the numbers of older persons (60+) grow from 901 million to 1.4 billion by 2030 and reach 2.1 billion in 2050 (WHO). Help Age India reported that the elderly population will reach to 143 million by 2021. Kerala has highest percentage of elderly almost 12.6 per cent of the population (Ministry of statics, 2016). Today's changed work-life, youngster's attitude, family and social structures, emigration of young family members has resulted in exclusion and emotional deprivation among the elderly forced to lead a lonely life. The survey was an attempt to investigate the Expatriate Keralite Individual attitude on their post retirement time planning.
\end{abstract}

\section{Materials and methods}

A quasi-experimental study was used to assess the attitudes of post retirement time plans among the 20 selected expatriate Keralite by using interview technique.

\section{Result}

Only $35 \%$ of the sample feels that it is necessary to plan for our retirement period. Half of the sample works for private firms and there is no security for them once they leave their job. Even though there is a need for planning their post retirement period they have not even think about it because they perceived that their family members feel sad to hear that they are coming back because they are only the source of income for their dependents. Ninety percentage of the sample did not realized that they have completed almost half part of their life and it is time for them to think wisely to plan ahead for their time left out to live.

\section{Conclusion}

Majority had not even started to think on about changes in life styles, activities and relationships. They need to be counseled to plan their time in post-retirement by time calculator and Middle age is the correct period to start planning what he or she will do in their second half of life.

Keywords

Counseling, expatriate Keralite, middle aged people, retirement period 